\title{
The Mower, The Sower, and The Mayor: Thomas Hardy and Hamo Thornycroft, Encounters and Affinities ${ }^{1}$
}

Jane E. Thomas [J.E.Thomas@hull.ac.uk]

English Department, University of Hull, Cottingham Road, HULL. HU6 7RX

\section{Notes on Contributors}

Jane Thomas is Reader in Late Victorian and Early Twentieth-Century Literature at the University of Hull. Her research includes the life and work of Thomas Hardy, Victorian literature and the visual arts, British women writers, and the literature of Hull and Holderness, including Larkin and Winifred Holtby. She is the author of Thomas Hardy, Femininity and Dissent and Thomas Hardy and Desire and has published on Hardy, Hamo Thornycroft, and ekphrasis. She is Academic Director of the Biennial International Thomas Hardy Conference and a Research Fellow of the Henry Moore Institute.

\section{Abstract}

This essay explores the intellectual and creative friendship between Thomas Hardy and Hamo Thornycroft, who met in 1883 when they were engaged upon works that were to define their respective careers. Hardy's The Mayor of Casterbridge and Thornycroft's The Mower testify to the concern of both artists to dignify with the permanence of art fleeting moments of collision between the old world and the new whilst striving to balance the desire to idealize with the imperatives of the real.

Keywords: sculpture, Thomas Hardy, Hamo Thornycroft, labour

In the early spring of 1887 Thomas Hardy and his wife Emma visited Rome where Hardy noted "The quality of the faces in the streets [...] Satyrs: Emperors: Faustinas."2 This is more than a passing comment on the genetic inheritance of nineteenth-century Romans, it is also a sculptural observation occasioned no doubt by the couple's visits to the museums and galleries of the ancient city. The sculptors whose work was so admired by Hardy and Emma - Praxiteles and Phidias among others - took their models from the streets of Athens and the countryside of Greece. After a visit to the Capitoline Museum in Rome, Emma noted in her 
diary that an Antonine copy of Praxiteles' Aphrodite of Knossos had "both [sic] little toes crumpled under as if she had worn boots." ${ }^{3}$

Hardy and Emma's comments testify to the aesthetic value placed by the classical and Hellenistic Greeks and their Roman imitators on the human face and the anatomy of the human body, and to the gradual erasure of the boundary between the sacred and the secular. Hardy's suggestion that the lineaments of the gods, goddesses and emperors of the ancient classical world could be traced in the physiognomy of ordinary men and women also extends to his understanding and portrayal of the lives of the rural inhabitants of the "partly real, partly dream-country" of Wessex. ${ }^{4}$ His interest in classical myths is evident from his first published novel Desperate Remedies (1871), where the names Cytherea and Aeneas are borrowed from Virgil's Aeneid, through to his swansong - the story of the sculptor Jocelyn Pierston's pursuit of the Ideal - The Well Beloved $(1892 ; 1897) .^{5}$ The narrator of The Woodlanders (1887) describes the rural hamlet of Little Hintock, where the action takes place, as:

one of those sequestered spots outside the gates of the world [...] where, from time to time, dramas of a grandeur and unity truly Sophoclean are enacted in the real, by virtue of the concentrated passions and closely knit interdependence of the lives therein. ${ }^{6}$

The novel that is most closely informed by the structure and conventions of Sophoclean tragedy, however, is Hardy's story of the rise and fall of a hay trusser: The Life and Death of the Mayor of Casterbridge: A Story of a Man of Character (1886). Hardy's aim as a novelist, as he summarized it in the "General Preface" to the 1912 Wessex Edition of his works, was "to preserve for my own satisfaction a fairly true record of a vanishing life." In addition to 
its tragic dimensions, the pastoral elegiac aspect of the novel has been widely remarked on. For Pamela Dalziel, its purpose is to "chronicle that process of change, the mid-century impact of the then modern upon this distinctly unmodern world." 8

Julian Wolfreys suggests that Hardy's narratives "foreground [...] the remnants of embedded pasts without narrative, or those in danger of being erased from modern narratives of cultural identity." He uses the term "spectrality" to describe "that force whereby ancient and modern come into confrontation, interrupting the quotidian," simultaneously working to emphasize and disrupt the realist project of Hardy's fiction. ${ }^{9}$ I suggest here that Hardy's invocation of sculptural tropes, and more particularly sculptural methods, in his portrait of the hay-trusser, Michael Henchard, mirrors a corresponding "spectrality" in Hamo Thornycroft's neo-classical sculptures The Mower and The Sower, in that all three are embodiments not only of the ineluctable traces of the ancient in the modern world, but also of the moment in which past and future collide. Each artwork also expresses the tragic consequences of that collision for those at the mercy of forces beyond their control. Hardy's Michael Henchard and Thornycroft's unnamed mower and sower dramatize the testimony of the unremarked victims of progress. They symbolize both transience and timelessness: the persistence of the ancient world and the fragility of the present in the face of the ever-pressing future.

These moments of collision or impact between the old world and the new are represented in The Mayor of Casterbridge in a series of tableaux - static or, as Gottfried Ephraim Lessing described them, "pregnant moments" - chosen by painter or sculptor to suggest the narrative possibilities more obviously expressed by poetry or prose. ${ }^{10}$ One such moment of dynamic stasis is referred to by the novel's narrator as a "transfixture." It occurs as Henchard spies though his telescope on the budding romance between Farfrae and Elizabeth-Jane from the vantage point of the pre-historic fort of Mai Dun. Scanning the 
"hedgeless $\mathrm{Via}$ " for a sight of his arch enemy Farfrae, Henchard is shocked to see Newson returning to Casterbridge to claim the daughter whom Henchard had informed him was dead:

Henchard dropped the glass, and for some seconds made no other movement. Newson waited, and Henchard waited - if that could be called a waiting which was a transfixture. $(288)^{11}$

This moment of temporary stasis - here highly suggestive of shock or powerful emotion on Henchard's part - suggests two narrative possibilities for him. The first, and morally correct, choice would be to confess his deception to Newson and Elizabeth-Jane thereby facilitating the reconciliation of father and daughter. The second, morally reprehensible but emotionally convincing, option is to allow the deception to remain until Newson's inevitable arrival exposes Henchard to the censure of both.

Not obviously sculptural perhaps, this "transfixture" is nevertheless suggestive of preceding and succeeding action in the way that Lessing describes the "pregnant moment," and the use of this device at other significant points in the narrative is often highly reminiscent of sculpture, and of the techniques that Hamo Thornycroft learned from his classical forebears. Thornycroft was perfecting these techniques, in what his champion Edmund Gosse called his "bucolic experiments," at the point when he and Hardy met and initiated a regular and engaging correspondence that lasted until the sculptor's death in December $1925 .{ }^{12}$

When Hardy and Thornycroft were introduced in June 1883, each was at a turning point in his personal and professional life: Hamo was probably the most talked-about sculptor of the day and Hardy the equally famous author of $A$ Pair of Blue Eyes, Far from the Madding Crowd and The Return of the Native. Both men were caught up in the new spirit of 
democracy abroad in the radical 1880s arising partly from the growth of Socialism and also from the debates preceding the Liberal Government's proposals to extend to male tenants in the rural districts the same concessions granted by the 1867 Reform Act to working men in the boroughs. The ensuing "Representation of the People Act" was passed in 1884. In July 1883 Hardy published a substantial essay on “The Dorsetshire Labourer” in Longman's Magazine in which he particularized for his middle-class readers the type of rural worker commonly referred to as "Hodge," making an informed and persuasive case for the Dorset cottager to be considered with "all the houseless and landless poor," and as part of "the vast topic of the Rights of Man."13 While Thornycroft's sculptures could hardly be classed as radical invocations of the democratic rights of the rural labourer, he was undergoing a political conversion in the 1880 s at the hands of the extraordinary woman he married in 1884 : Agatha Cox. At the same time Hardy was busy developing his knowledge of classical and neo-classical sculpture. In this last endeavour he found a willing tutor in Edmund Gosse who was his close friend until Hardy's death in 1928. Ann Thwaite dates the start of their connection from the late winter of 1874. In 1912 Gosse wrote to Hardy: "if we live two years more (and we will) our friendship will have lasted forty years." ${ }^{14}$ As both were to live for another sixteen years they were in fact friends for over half a century. Gosse began writing about contemporary sculpture in the early 1880 s and in 1883 he introduced Hardy to Thornycroft, with whom he was engaged in a long and deeply affectionate friendship, and whom he regarded as the leading light of the "New Sculpture," a movement Gosse influentially described and defined in his four-part series of articles for The New Art Journal in 1894. Hardy had begun work on The Mayor of Casterbridge and Thornycroft was modelling his much feted sculpture The Mower, which was first exhibited at the Royal Academy in 1884, and was then followed by The Sower in 1886, the year that Hardy's Mayor 
was serialized simultaneously in the Graphic and Harpers Weekly, before being issued in novel form in May.

Frederic Leighton's bronze sculpture, Athlete Wrestling with a Python, is generally regarded as initiating the 'New Sculpture' movement in England. ${ }^{15}$ The piece was first seen at the Royal Academy Summer Exhibition in 1877 and was regularly on view at the South Kensington Museum along with other works purchased for the nation. As David Getsy has indicated, Leighton's Athlete became 'one of the most recognizable sculptures of the late Victorian era and served as a popular cultural reference for cartoons and advertisements'. ${ }^{16}$ It was an iconic work that appeared to combine the expressive and the naturalistic potential of sculpture for the British art world of the period. Gosse noted that the Athlete Wrestling with a Python (or Strangling a Python as it was referred to) had been placed apart from the other sculptures and among the paintings in the Lecture Room. This "seemed to suggest its solitary state in relation to the other statuary of the year." He detected a "wholly new force" in the piece expressed in "a series of surfaces, varied and appropriate, all closely studied from nature" that gave "the start word" to the "New Sculpture" (Gosse, 1894: 140). Michael Hatt has specified the appeal of Leighton's piece:

It is a classical figure, appealing to certain paradigmatic ways of thinking about the body in its emphasis on health, on the equation of the physical and the moral, and on heroic embodiment; and yet it is also decisively modern in technical terms, suggesting the persistence of ideals across time and finding a home in the bodies of Victorian men. ${ }^{17}$ 
In addition to being a regular attendee at Royal Academy exhibitions, Hardy was acquainted with Leighton and visited his studios. He would have been familiar with Thornycroft's work before their meeting, however, as the younger man had already won the Academy Gold Medal for sculpture in 1875 with his first exhibit $A$ Warrior Carrying $a$ Wounded Youth from Battle, narrowly defeating Alfred Gilbert whose study of the same subject was dismissed by Gosse as depicting "a wild Celtic or Gaulish warrior, with the youth flung across a hairy pony" (Gosse, 1894: 141). In Thornycroft's entry Gosse detected "something of the tenderness in the articulations of the joint, something in the freshness of the action and the harmony of lines" that prophesied the future of the young sculptor who at that point was struggling to free himself from the influence of his English neo-classical tutor John Flaxman (Gosse, 1894: 141). Gosse suggests a more successful integration of the contemporary and the classical in the Warrior than Flaxman was able to achieve and Thornycroft's sculpture was exhibited in the Central Hall of the Royal Academy as if to emphasize its radical and effective synthesis of apparently competing styles.

Four years later Thornycroft's life-size plaster of Artemis and her Hound also won the Royal Academy's gold medal and he was commissioned by the Duke of Westminster to execute the figure in marble for his new house Eton Hall. The plaster was exhibited again at the 1880 Royal Academy Exhibition where it caused a sensation due to its Greek lines and a delicacy of modelling which Thornycroft had developed through his intense study of human anatomy. For his part, Gosse was delighted with Thornycroft's sculpture, and the knowledge that he had worked on it by moonlight led him to declare in a letter dated October, 1879: "It strikes me as a noble subject for a poem - a great sculptor, born with a Greek heart into bigoted Christian times, and carving for himself, by stealth at night, an image of the glorious goddess. It would mingle the sense of art with the sense of worship." 18 
Thornycroft was elected ARA in 1881, even though there was no vacancy, and his figure of Teucer - the legendary archer and founder of the city of Salamis - was placed at the entrance to the Lecture Room where, according to Gosse, it excited much attention from a “public which sculpture had long ceased to awaken." He added: "The virile and slightly archaic statue was a direct answer to those who had prophesied that the elements of lyric grace and delicate refinement would alone prove to be at the command of the young artist" (Gosse, 1894: 201). Gosse also quoted Millais' approving comment that "were [Teucer] dug up from under oyster-shells in Rome or out of Athenian sands, with a cachet of partial dismemberment about it, all Europe would straight away fall into ecstasy, and give forth the plaintive wail, 'We can do nothing like that now'” (Gosse, 1894: 202).

In both Artemis and Teucer, Thornycroft was beginning to specify the defining principles of the New Sculpture developing, to quote Susan Beattie, "the potential of form and line to express electrifying energy and emotion."19 Thornycroft depicts Artemis in the act of selecting an arrow while her eyes focus on her quarry. One hand leans down to restrain her hound. A diagonal line extends from the other hand, poised on the flight of the chosen arrow, right down to the dog's nose indicating the line and direction of the arrow's trajectory. The same is true of Teucer whose subject intently follows the flight of the fatal arrow at the very moment of its release. It is this sense of a moment of action captured and frozen for ever in marble or bronze, which also carries with it - in the dynamism of the piece itself - the suggestion of the ensuing movement, that seemed so fresh to Academy critics and visitors in the early 1880s. But Thornycroft was to develop the neo-classical theme in an even more startling way, heralding, in England, the birth of a new democratic form of art that was to find its match in the work of Thomas Hardy.

Hardy first mentions Thornycroft on the eve of the New Year of 1884 at a party in the company of Henry James and Edmund Gosse. Hardy's biographer, Michael Millgate, dates 
their acquaintance a year earlier to a private dinner arranged by Gosse at the Rabelais Club on 25 June 1883, at which Hardy was introduced to both Thomas Woolner and Thornycroft. ${ }^{20}$ In a letter to Gosse, congratulating him on the success of the dinner, Thornycroft wrote:

The artists proved themselves equal to hold forth in conversation with the famous literary men of the company. Was not Woolner loquacious and how charming Du Maurier.

He added: "Hardy \& I had a nice talk about country folk." 21

According to Hamo's daughter, Elfrida Manning, a warm friendship grew up between Hardy and Thornycroft "based on their shared passion for country folk and country ways." 22 Hardy was particularly taken with Thornycroft's wife Agatha who had declared herself a Positivist aged thirteen and was a firm believer in "land reform, Malthusianism, Votes for Women, Home Rule for Ireland and the Abolition of War" (Manning, 1982: 87). On 8 May 1894 Hamo wrote to Agatha telling her of Gosse's anecdote that Hardy thought her "the most beautiful woman in England" and that it was she "on whom I thought when I wrote Tess of the d'Urbervilles" (Manning, 198: 88). In 1889, Hardy noted in his diary: "Of the people I have met this summer, the lady whose mouth recalls more fully than any other beauty's the Elizabethan metaphor "Her lips are roses full of snow" [...] is Mrs H T --- whom I talked to at Gosse's dinner."23 Agatha also influenced Thornycroft's conversion to Socialism and his new-found, if somewhat naïve, respect for the working man, as he confided to his journal in March, 1885: "I am become a radical and feel infinitely happier for the change. Every workman's face I meet in the street interests me, and I feel sympathy with the hard-handed toilers \& not the with the lazy do nothing selfish 'upper-ten'.,24 
On 8 April 1884, Thornycroft sent a life-size sculpture in plaster to the Royal Academy Exhibition. ${ }^{25}$ His model was an Italian farmer, Orazio Cervi, who regularly walked from his farm in the Abruzzi to London to pose for Thornycroft at sittings that sometimes lasted for seven hours without a break. ${ }^{26} \mathrm{He}$ dated the inspirational moment for The Mower to a boat trip on the upper reaches of the Thames in the company of Gosse in 1881. On a stretch of the river near Marlow in Buckinghamshire he saw a farmhand pausing from his labour on the bank to watch them pass by, and was reminded of lines from his favourite poet, Matthew Arnold. The entry in the exhibition catalogue featured the title of the piece - The Mowerand an epigraph taken from the thirteenth decima of Arnold's “Thyrsis" (1866), his elegy for the poet Arthur Clough who died in Florence at the age of 42: "Where are the mowers, who, as the tiny swell / Of our boat passing heaved the river-grass, / Stood with suspended scythe to see us pass?"27 A visit by the poem's narrator to the Cumnor Hills above Oxford and the villages of South and North Hinksey elicits an extended meditation upon change, transience and loss, as it is manifested in the villages themselves and the disappearance of their previous inhabitants who worked in the nearby fields. This sense of change and loss is echoed in the death of Clough, Arnold's walking companion when both were at Oxford. Although omitted from the epigraph, the last line, "They are all gone, and thou art gone as well," 28 provides the unspoken response to the question posed, placing the modern subject of the sculpture in an intertextual relationship with Virgil's Eclogues, the Idylls of Theocritus and the tragic poetry of Sositheus. The delicate modelling of the piece testifies to Thornycroft's love of Greek sculpture - specifically Phidias and Praxiteles - and his detailed study of the anatomy of the human body. ${ }^{29}$ In its execution it combines elements of English realism with the innovations of the modern "French" tradition developed by Jules Dalou and the Belgian sculptor Constantin Meunier. In addition, it combines elegy with social comment: Thornycroft's mower is caught in contrapposto (echoing the pose of Michael Angelo's David and of the 
sculpture of the same name by Donatello (c. 1440)), whose work Thornycroft had much admired during his visit to Italy in 1872. The contrapposto echoes the Belvedere Apollo although Thornycroft's decision to clothe the figure in the authentic costume of a Victorian rural worker, and his delicate modelling of Cervi's face signifies the young sculptor's radical reworking of both styles. The temporal and the spatial combine in The Mower to suggest a number of narrative possibilities. In its immediate and realistic moment, the mower shifts his weight preparatory to returning to work in the field behind him. In its elegiac moment he steals away, ceding his place to the mechanical reapers that were rapidly appearing in the fields of England and Scotland. At the same time, in the gallery his gaze fixes the middleclass metropolitan viewer (as Thornycroft was fixed by the gaze of the original) as if calling attention to the labourer's right to proper and sympathetic consideration at this time of proposed constitutional reform. Furthermore, the epigraph - combined with the suggestive archaic stance of the piece - invests the "pregnant moment" with Wolfrey's notion of "spectrality." The countryside of late nineteenth England is linked to a vanished ideal Pastoral world, and the mower is imagined as a contemporary personification of Daphnis reaping "the perilous grain/ in the hot cornfields of the Phrygian king" Lityerses. Unlike Daphnis however, Thornycroft's mower will not succeed in the reaping competition, which in his case will be against progress in the shape of increasingly mechanized methods of farming which will eventually efface him from the countryside and from history. ${ }^{30}$ In this respect his condition mirrors that of Michael Henchard from The Mayor of Casterbridge.

In July 1887 Hardy confided to his journal: "It is the on-going — i.e., the 'becoming' — of the world that produces its sadness. If the world stood still at a felicitous moment there would be no sadness in it." ${ }^{11}$ Hardy's moments of "transfixture" may not necessarily be "felicitous," but they mark points in the temporality of the narrative when felicity and sadness are held in a dynamic and productive tension. We might think of the "pregnant moment" 
when the flight of a swallow through the furmity tent temporarily disrupts Henchard's drunken attempt to sell his wife:

In watching the bird till it made its escape the assembled company neglected to respond to the workman's offer, and the subject dropped. But a quarter of an hour later the man $[\ldots]$ recurred to the old strain again. (11)

Towards the novel's close, a humbled and repentant Henchard returns to what he believes to be the exact spot on which the transaction occurred a quarter of a century earlier as if to turn back time to that decisive moment that was determine his future, and choose differently:

It was not really where the tent had stood, but it seemed so to him "Here we went in, and here we sat down. I faced this way. Then I drank, and committed my crime. It must have been just on that very pixie ring that she was standing when she said her last words to me before going off with him: I can hear their sound now, and the sound of her sobs." (296)

Indeed, Henchard's reappearance in "the working clothes of his young-manhood" forming "much the same picture as he had presented when entering Casterbridge for the first time nearly a quarter of a century before" seems, momentarily, to efface what has occurred in the interim except that, as the narrator informs us, the tale is expressed in the attenuated "spring of his stride" and the "perceptible bend" of his shoulders, "as weighted by the basket," testifying to the weakening effect of his state of hopelessness (290). Henchard's hopeless 
state owes its origin not just to "the serious addition to his years" but to what Hardy terms the moments of becoming for whose outcomes Henchard is wholly responsible. These add the weight of their oppression to those moments of collision between the old world and the new, which, like Thornycroft's mower, he is unable to withstand.

Hardy does employ suggestively sculptural tropes throughout The Mayor of Casterbridge. He invokes the very sculpture Lessing uses to illustrate the 'pregnant moment' -- the Hellenistic group known as Laocoön and his Sons - to describe the ancient espaliered fruit trees in Henchard's garden, soon to be lost to Farfrae and eventually inherited by Elizabeth-Jane as Farfrae's second wife:

The long-tied espaliers, as old as the old house itself, had grown so stout, and cramped, and stood distorted and writhing in vegetable agony, like leafy Laocoöns. (72)

However, it is in Henchard's dealings with the agent of change himself - Donald Farfrae that the sculptural moment finds its most poignant expression. Shunned by the residents of Casterbridge following his bankruptcy, and publically manhandled out of the presence of the Royal Visitor by the new mayor, Henchard lures his enemy to the top floor of the granary with a view to wrestling him out of the door and to his death forty feet below. As Alison Fisch-Katz has noted, Henchard's wrestling match with Farfrae takes place in view of the Laocoönian fruit trees of what is now Farfrae's garden, but it is the description of the two men, locked in combat, that embodies both the "pregnant moment" and the spectral confrontation between the ancient and the modern world. ${ }^{32}$ At one point the antagonists appear equally matched: "Several minutes were passed by them in this attitude, the pair 
rocking and writhing like trees in a gale, both preserving an absolute silence" (253) until Henchard gains the upper hand:

deliver[ing] the younger man an annihilating turn by the left fore-hip [...] and following up his advantage, [Henchard] thrust him towards the door, never loosening his hold till Farfrae's fair head was hanging over the window-sill, and his arm dangling down outside the wall. (254)

The narrator tells us that the initial coming together of the two men "had very much the appearance of the ordinary wrestling of those parts" (253) but at the point at which Henchard prevails over his opponent, the description of the two men closed in struggle suggests the Roman copy of a marble piece known as The Wrestlers or The Pancrastinea in the Uffizi collection in Florence. The image of Farfrae and Henchard locked in mortal combat, can be read as a material evocation of the collision between two worlds: the crude "viva voce" of Henchard's and the modern system of letters and ledgers initiated by Farfrae (85). As with Thornycroft's Mower, the contemporary depiction of the displacement of the old by modern farming methods is given an elegiac quality through the evocation of a lost classical world, and though Henchard wins the wrestling contest by brute strength, he cannot prevail against the force of progress. This forms one of the rare moments of transfixion in which Henchard makes the correct moral choice, when the call of the other disrupts his egotistical compulsion. Faced with his imminent demise Farfrae unwittingly reminds Henchard of the implication of his action: that it is but the inevitable outcome of the older man's apparently murderous hatred of the younger. That Henchard has rarely thought about these implications - choosing instead to give way to the passion of the moment - increases his growing self-contempt: "“Go and give me in charge - do what you will - I care nothing for what comes of me"” (254). 
Nowhere is the obliterating force of the future more clearly indicated than in the scene where Farfrae extols the virtues of his new agricultural machine to a sceptical Lucetta and Elizabeth-Jane.

It was a new-fashioned agricultural implement called a horse-drill, till then unknown in its modern shape, in this part of the country, where the venerable seed-lip was still used for sowing as in the days of the Heptarchy. [...] The machine was painted in bright hues of green, yellow, and red, and it resembled as a whole a compound of hornet, grasshopper, and shrimp, magnified enormously. (156)

This garish and monstrous modern hybrid is set against the hitherto enduring farming methods of the ancient kingdoms of Britain, and also against the New Testament parable telling of the difficulties that beset the word of God as it struggles to take hold in the hearts of men. Farfrae declares:

"It will revolutionize sowing hereabout. No more sowers flinging their seed about broadcast, so that some falls by the wayside, and some among thorns, and all that. Each grain will go straight to its intended place, and nowhere else whatever!"

"Then the romance of the sower is gone for good," observed Elizabeth-Jane [.... " 'He that observeth the wind shall not sow,' so the Preacher said; but his words will not be to the point any more. How things change." (158) 
Farfrae's voice, humming a song from inside the machine, links him to the myth of the Trojan horse sent to beguile and ultimately defeat the citizens of Troy and Henchard's scepticism concerning the machine, and Farfrae's belief in it, again suggests the figure of Laocoön, who famously distrusted Greeks - especially those bearing gifts. Elizabeth-Jane’s lament for the "romance of the sower" is elegiac but also functions as a comment on the modern zeitgeist. In the new age of farming, seeds will not be scattered by men but literally "drilled" into their pre-determined positions in the field by machines regardless of the weather. At the same time, she suggests that the modern age will have no time for those who do not, or cannot, embrace the future. Machines will increase the efficiency of human action, inevitably breaking the bond between the labourer and the soil and between human beings and the natural world. The image of the sower also brings to mind St Paul's warning to the Galatians: "whatever a man soweth that shall he also reap" (6: 7-9), acting as a comment on the implications of Henchard's past, and future, conduct.

Thornycroft's embodiment of the "romance of the sower," with all its intertextual implications, was exhibited at the Royal Academy in 1886, where it was much admired by many including the poet Gerard Manley Hopkins. ${ }^{33}$ Like its predecessor, The Mower, the lifesize sculpture The Sower combines elements of French realist sculpture - specifically Henri Gauquiè's Le Semeur, which was exhibited in the Paris Salons in the 1880s - with classical forms. Thornycroft reverses the contrapposto of the Belvedere Apollo so that the sower's weight is thrown upon his leading foot, giving the figure a forward momentum indicative of concentrated purpose. By the time the sculpture was exhibited, Hardy's The Mayor of Casterbridge was published in novel form, but it is interesting to speculate whether the imminent demise of The Sower from the English countryside formed part of Thornycroft and Hardy's "nice talk about country folk." 
Both Hardy and Thornycroft were concerned with the ways in which elements of classical myth and tragedy, pastoral elegy and even stories from the Scriptures could be used to heighten the expressivity of a work of art. In the case of The Mower, The Mayor and The Sower the aesthetic and emotional reach is intensified and extended by means of textual and inter-textual references, which borrow their power from narrative and plastic art forms. For both artists this complex borrowing was central to the distinction between art and reality. The melding of classical forms with contemporary plebeian content, and the blending of imagination and reality in the depiction of the "partly real, partly dream-country" of Wessex, informs Hardy's conception of Art. The role of the artist, he claims, is to lift the basic matter of life onto a higher plain through "the exercise of the Daedalian faculty for selection and cunning manipulation." 34

In his Royal Academy Lecture of 1885, Thornycroft reminded his students that "Art must have an aim of its own, and that aim cannot be mere copying with scientific exactness." 35 The duty of art, and specifically sculpture, was not to express the miseries of a nation but to fulfil man's need for "the expression of beauty and grace, of sentiment and character" (216). Art is the means through which "the ever-changing and evanescent forms and effects in nature, which are constantly before man and which astonish and perplex him, can alone be arrested \& permanently expressed. Art can thus interpret nature to man and teach him to perceive her beauty." (215)

Thornycroft emphasized the need for heightened verisimilitude in sculpture, whilst avoiding what he termed "the evils of excessive imitation," which he detected in the "fleshliness of Rodin." "The Art of Sculpture" he declares, "is a language whose special province is the expression of beauty of Form." The expression of sentiment and character is a secondary consideration (216). The forms in nature that provide the best materials for this language are firstly those "which constitute nature's highest organism, Man" and next to that 
"man's raiment or that which clothes him." Scorning the Restoration tradition of portraiture, Thornycroft insists: "All good art is representative of the age that produces it, so manifestly in representing that in which we live, we ought not to drape our statues as either the Greeks or the Romans did [...] it is our duty to express in Art the dress of our own time even though it may be difficult in so many cases to satisfy ourselves that it is aesthetically beautiful." He concludes:

We find that the most Sculpturesque garments we possess now-a-days are those where the dress has adapted itself most naturally to the occupation of the wearer, and the longer it has been worn the more worthy it is of your study. The folds instead of falling accidentally first in this direction and then in that have discovered their proper place and fall there with a certainty that has become a principle.

Even the thickest and most stubborn of material, such as leather, becomes valuable to the artist when worn long enough; it is not necessary to accentuate the patches and holes and ugliness; these are accidental while the folds are essential. It is quite extraordinary how the human figure will assert its form through clothing after long wear; the effect assumed is of course the typical and for that very reason of most value to the sculpture. (218)

He goes on to note how even in London "one sees, not infrequently, among the navvies, or those workmen who dig out the foundations of buildings, men who look 'Sculpturesque' in their wrinkled corduroy trousers, buckled in at the knee with a strap, with a loosely-fitting shirt, soft and pliable." He stresses here not just the importance of ensuring that the form of a 
figure is not sacrificed to a desire to slavishly imitate its clothing but also the way in which the depiction of the clothing can contribute to the aesthetic or Sculpturesque quality of a subject. Indeed, Thornycroft went to great lengths to establish the authentic appearance of his Mower using a farm labourer as his model and basing the boots on a pair borrowed from a local navvy. He also adapted the finished piece changing the position of the scythe and removing the shirt so as to emphasize the anatomical details of the figure's toned physique.

In Thomas Hardy Writing Dress, Simon Gatrell notes how in some circumstances the boundary between body and dress is vague, indistinguishable or permeable and gives rise to considerable psychological complexity. ${ }^{36}$ Dress "carries forth a version of our self into the world whether we like it or not" (4) and that this is clearly demonstrated in the case of Michael Henchard in that "what he wears is always important in evaluating the development of his personality" (10). Gatrell explores this in some detail, but it is worth noting here the precision with which Hardy's description of Henchard's clothes on the first page of the novel expresses something fundamental, about the labourer's form while adding, dynamically, to the expression of his character.

The man was of a fine figure, swarthy, and stern in aspect; and he showed in profile a facial angle so slightly inclined as to be almost perpendicular. He wore a short jacket of brown corduroy, newer than the remainder of his suit, which was a fustian waistcoat with white horn buttons, breeches of the same, tanned leggings, and a straw hat overlaid with black glazed canvas. At his back he carried by a looped strap a rush basket from which protruded at one end the crutch of a hay-knife, a wimble for hay-bonds being also visible in the aperture. His measured springless walk was the walk of a skilled countryman as distinct from the desultory shamble of the general labourer; - while in the 
turn and plant of each foot there was, further, a dogged and cynical indifference, personal to himself, showing its presence even in the regularly interchanging fustian folds, now in the left leg, now in the right, as he paced along. (5)

Henchard's personality can be detected not just in his air of self-absorption or even in his stride but in the relentless, almost mechanical, creasing of the cloth of his heavy cotton breeches at the back of his knees as he paces "with a dogged and cynical indifference" to all around him. As he leaves Casterbridge with the same "creases behind his knees," all the pain and the glory of those intervening twenty-five years is expressed in the slowness of his step and the "perceptible bend of his shoulders." For Hardy the expression of sentiment and character is the primary role of art and his sensitivity to the ways in which this can be communicated through small imperfect details deepens and supplements Thornycroft's ideas on expressivity in sculpture.

There are similarities, and also profound differences, in both men's conception of the nature and purpose of art. On 3 January 1886 - the day following the appearance of the first instalment of The Mayor of Casterbridge in the Graphic - Hardy commented:

in these Bible lives and adventures there is the spherical completeness of perfect art $[\ldots .$.$] Is not the fact of their being so convincing, an$ argument, not for their actuality, but for the actuality of a consummate artist who was no more content with what Nature offered than Sophocles and Pheidias were content. ${ }^{37}$ 
In "The Profitable Reading of Fiction,” published in the New York Forum in March 1888, Hardy again turned to sculpture to illustrate his point, this time to a Roman copy of a Greek original, known to him as The Dying Gladiator, which he and Emma had seen in Rome the previous year:

no real gladiator ever died in such perfect harmony with normal nature as is represented in the well-known Capitoline marble. There was always a jar somewhere, a jot or tittle of something foreign in the real death-scene, which did not essentially appertain to the situation, and tended toward neutralizing its pathos; but this the sculptor omitted, and so consecrated his theme. ${ }^{38}$

It is perhaps this idea of the consecration of the theme that separates Thornycroft and Hardy. For the writer and Hellenist John Addington Symonds, who looked to the bodies of workingclass men for personal and sexual salvation, the future lay in the hands of the labouring classes. For Thornycroft it was a matter of aesthetics, although his life-size studies of seminude labourers clearly have an erotic appeal to both sexes and were especially popular with the excessively clothed and often voyeuristic metropolitan gallery visitor.

At the time of their first meeting, Thornycroft and Hardy appear to have shared what Symonds, who was a great admirer of the work of both men, termed "the right democratic spirit" and the belief that the role of art was not simply to copy life but to give it "permanence, dignity, repose, elevation" by applying the selective imagination of the artist which constitutes the "differentia of art." ${ }^{39}$ However, Hardy's aim was neither erotic nor idealistic but to make a deep emotional connection with his readers. It is the inclusion of that "jar ... of something foreign" that gives an emotional force to Hardy's characters that 
Thornycroft's elegiac, idealized figures - for all their aesthetic perfection - lack. Thornycroft's dismissal of the "evils" of the "fleshliness of Rodin" in his 1885 Royal Academy Lecture suggests the extent to which the artistic paths of both men were to diverge though they remained close friends until Thornycroft's death, Hardy sitting for a portrait bust in marble which was later cast in bronze and exhibited at the Royal Academy in 1916. Unlike Hardy, Thornycroft's portraits of working men never demonstrate the marks of labour on the flesh. ${ }^{40}$ By the close of The Woodlanders Marty South is transfigured by moonlight into a translucent icon:

a straight, slim figure, clothed in a plaitless [ie without folds] gown, the contours of her womanhood so undeveloped as to be scarcely perceptible in her, the marks of poverty and toil effaced by the misty hour, she touched sublimity at points, and looked almost like a being who had rejected with indifference the attribute of sex for the loftier quality of abstract humanism. ${ }^{41}$

We cannot easily forget, however, that hand reddened and blistered by the bill hook, "as if her present occupation were as yet too recent to have subdued it to what it worked in." (10) By the 1890s there was a new enthusiasm among English writers and artists for the work of Rodin, whom the Royal Academy had castigated in 1886 as "the Zola of sculpture" deploring his presentation of the body, physicality and sexuality. ${ }^{42}$ This degree of somatic engagement was anathema to Thornycroft, but a decade after the publication of The Mayor of Casterbridge Hardy was to fully engage with such issues in his own Zolaesque novel Jude the Obscure in what was also widely regarded as an affront to public decency. 
${ }^{1}$ I am grateful to the Henry Moore Institute for awarding me a month-long research fellowship in 2013, which allowed me to undertake much of the research that informs this essay.

${ }^{2}$ The Life and Work of Thomas Hardy by Thomas Hardy, ed. Michael Millgate (Basingstoke: Macmillan, 1984), 196.

${ }^{3}$ Emma Hardy Diaries, ed. Richard H. Taylor (Ashington: Mid Northumberland Arts Group; Manchester: Carcanet New Press, 1985), 149.

${ }^{4}$ Thomas Hardy, "Preface" to the 1912 edition of Far from the Madding Crowd in Thomas Hardy's Personal Writings, ed. Harold Orel (Basingstoke: Macmillan, 1966), 8-11, at 9. ${ }^{5}$ See Jane Thomas, “Art, Aesthetics and Masculine Desire: The Well-Beloved (1897),” in Jane Thomas, Thomas Hardy and Desire: Conceptions of the Self (Basingstoke: Palgrave, 2013), 144-63.

${ }^{6}$ Thomas Hardy, The Woodlanders (Oxford: OUP, 2005), 8.

${ }^{7}$ Thomas Hardy, "General Preface to the Novels and Poems," Wessex Edition, I, 1912, in Thomas Hardy's Personal Writings, ed. Harold Orel (Basingstoke: Macmillan, 1966), 44-50, at 46.

${ }^{8}$ Pamela Dalziel, "Introduction" to The Mayor of Casterbridge (Oxford: OUP, 2004), xiiixxxiv, at xvii. Subsequent quotations from this novel will be taken from this edition.

9 Julian Wolfreys, Thomas Hardy (Basingstoke: Palgrave, 2009), 165-66. 
${ }^{10}$ See Grant F. Scott, The Sculpted Word: Keats, Ekphrasis and the Visual Arts (Hanover and London: University of New England Press, 1994), 3.

${ }^{11}$ It would appear that Hardy coined this word to describe " $[t]$ he condition of being transfixed or fixed to the spot with some feeling" as the $O E D$ quotes this passage as the first instance of its use; see Dale Kramer's explanatory note to page 288 of The Mayor of Casterbridge (Oxford: OUP, 2004).

${ }^{12}$ Edmund Gosse, “The New Sculpture 1879-94," The New Art Journal (1894): 138-42; 199$203 ; 277-82 ; 306-11$, at 282 . Subsequent references to this set of articles are in parentheses in the text of the essay.

13 Thomas Hardy, “The Dorsetshire Labourer,” Longmans' Magazine 2 (July 1883): 252-69; in Thomas Hardy's Public Voice: The Essays, Speeches, and Miscellaneous Prose, ed. Michael Millgate (Oxford: Clarendon, 2001), 37-57, at 57.

${ }^{14}$ See Ann Thwaite, Edmund Gosse: a Literary Landscape 1849-2007 (London: Secker and Warburg, 1984), 222-24.

${ }^{15}$ Gosse dates the movement to France and Francois Rude's Young Neapolitan Fisherman exhibited at the Paris Salon in 1833. He claims, however, that no French influence penetrated “our hide-bound conventions" until the appearance of Loison, Carpeaux, Carrier-Belleuse (1873) and more importantly perhaps, Jules Dalou at the Royal Academy in 1874. But it was the Paris Salon of 1876 that for Gosse, at least, "provided the starting-force which set the New Sculpture moving in England”. Gosse, "The New Sculpture 1879-94”, The New Art Journal (1894): 140.

${ }^{16}$ David Getsy, Body Doubles: Sculpture in Britain, 1877-1905 (New Haven: Yale University Press, 2004), 15 
${ }^{17}$ Michael Hatt, "Substance and Shadow; Conceptions of Embodiment in Rodin and the New Sculpture," in Rodin: the Zola of Sculpture, ed. Claudine Mitchell (Aldershot: Ashgate, 2004), 217-235, at 220.

${ }^{18}$ Edmund Gosse to Hamo Thornycroft, August 1879, in Evan Charteris, The Life and Letters of Edmund Gosse (New York and London: Harpers and Brothers; 1931), 112.

${ }^{19}$ Susan Beattie, The New Sculpture (New Haven: Yale University Press, 1983), 1.

${ }^{20}$ The Life and Work of Thomas Hardy by Thomas Hardy, ed. Michael Millgate

(Basingstoke: Macmillan, 1984), 170.

${ }^{21}$ Hamo Thornycroft to Edmund Goss (BC 19c Ms Gosse, Brotherton).

${ }^{22}$ Elfrida Manning, Marble and Bronze: The Art of Hamo Thornycroft (London: Trefoil Books, 1982), 169.

${ }^{23}$ The Life and Work of Thomas Hardy by Thomas Hardy, 230.

${ }^{24}$ Manning, Marble and Bronze, 93.

${ }^{25}$ Although the plaster was much praised at the Academy, it was not cast in bronze on this scale until commissioned, uniquely, by the Walker Gallery, Liverpool in 1894 . The bronze was then exhibited at the Royal Academy Summer Exhibition from the 7 May to 6 August of that year. See "The Exhibition of the Royal Academy of Arts, The One Hundred and TwentySixth (Summer Exhibition), 1894," Mapping the Practice and Profession of Sculpture in Britain and Ireland 1851-1951, University of Glasgow History of Art and HATII, online database 2011 [http://sculpture.gla.ac.uk/view/event.php?id=msib7_1217941512], accessed 11 Jan 2015. The catalogue entry for Thornycroft's full-sized plaster Teucer, exhibited at the 1881 Royal Academy Exhibition, featured an extract from Alexander Pope's translation of the Iliad.

26 "Orazio Cervi has been sitting to me for the 'Mower' from 10 till 5"; Hamo Thornycroft to Agatha Cox, 4 October 1883, Hamo Thornycroft Archive, Henry Moore Institute TII-C-T 
$[\mathrm{H}] 71$.

${ }^{27}$ For a discussion on the ekphrastic implications of this epigraph see my forthcoming essay “Close Encounters of the Third Kind, Hamo Thornycroft's The Mower (1884) and Matthew Arnold's 'Thyrsis' (1866): Desire, Reverse Ekphrasis and the Intermedial Artwork," in Ekphrastic Encounters: New Interdisciplinary Essays on Literature and the Visual Arts, eds Meek Richard and David Kennedy (Manchester: MUP, 2017), 169-84.

${ }^{28}$ Matthew Arnold, "Thyrsis," in The Poems of Matthew Arnold, ed. Miriam Allott, Longmans Annotated English Poets (London and New York: Longman, 1979), 1. 130.

${ }^{29}$ In a birthday letter to Agatha Cox written on 24 August 1882, Thornycroft declared: "Greek art is so full of unassuming knowledge, so true to nature, so simple, so refined, so fascinating \& stimulating to the imagination. I always feel the better \& happier from contemplating it." Hamo Thornycroft Archive, Henry Moore Institute: TH-C-T [H] 6.

${ }^{30}$ Thomas Dobbs of Birmingham had invented a mechanical reaper as early as 1814 and the horse-drawn mechanical reaper was introduced into England in the 1870s.

${ }^{31}$ The Life and Work of Thomas Hardy by Thomas Hardy, 210.

${ }^{32}$ See Alison Fisch Katz, The Dialectic of Word and Image in the Selected Fiction of

Thomas Hardy, unpublished PhD thesis, Leeds University, 2009, 129 and 149.

${ }^{33}$ See John Stuart Roberts, Siegfried Sassoon (London: John Blake Publishing, 2014), 10.

34 Thomas Hardy, “The Science of Fiction," New Review (1891): 315-19; reprinted in Thomas Hardy's Personal Writings, 134-38, at 135.

${ }^{35}$ W. Hamo Thornycroft, Lecture to the Sculpture Students of the Royal Academy, 1885. The presentation holograph of the lecture in the Henry Moore Institute Archive, Leeds (Thornycroft papers Y2-2) is reprinted in David J. Getsy, "The Problem of Realism in Hamo 
Thornycroft's 1885 Royal Academy Lecture,” The Walpole Society 69 (2007): 211-25, at 215.

${ }^{36}$ Simon Gatrell, Thomas Hardy Writing Dress (Oxford: Peter Lang, 2011), 3.

${ }^{37}$ The Life and Work of Thomas Hardy, 177.

${ }^{38}$ Hardy, “The Profitable Reading of Fiction,” Forum (March 1888): 57-70; reprinted in Thomas Hardy's Personal Writings, 110-25, at 117.

${ }^{39}$ See John Addington Symonds to Hamo Thornycroft, 24 October 1884, Henry Moore Institute Archives: Thornycroft II; C 616.

${ }^{40}$ Sue Bridehead sees a nobility "in a man's hand subdued to what he works in." Thomas Hardy, Jude the Obscure (Oxford: OUP, 1998), 137.

41 Thomas Hardy, The Woodlanders, ed. by Dale Kramer, with a new introduction by Penny Boumelha (Oxford: OUP, 2005), 331.

${ }^{42}$ See Claudine Mitchell, "Introduction: Crossing Borders, Negotiating Culture," in Rodin: the Zola of Sculpture, 1-16, at 8. 


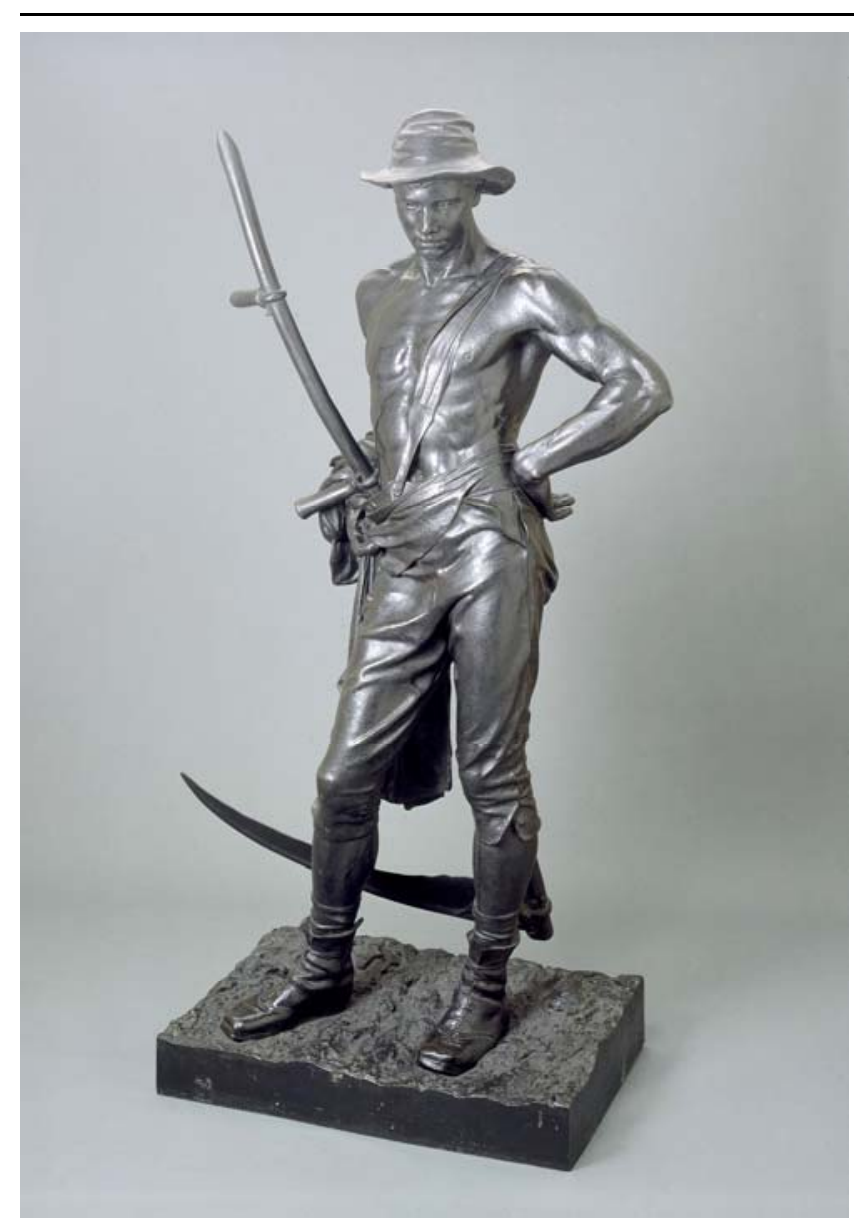

Hamo Thornycroft, The Mower (1894), bronze, National Museums Liverpool, Walker Art Gallery. 